\section{招uflic 瑟ealty.}

\section{THE METROPOLITAN BRANCH OF THE SOCIETY OF MEDICAL OFFICERS OF HEALTH.}

Turs branch was constituted in July, 189 r. Mr. S. R. Lovett was elected president; Mr. Shirley Murphy, Professor Corfield, Dr. T. Orme Dudfield, and Dr. Septimus Gibbon were elected vicepresidents ; Dr. Kempster was elected treasurer; and Dr. Louis Parkes was elected honorary secretary.

Bye-laws have been adopted. They are very similar to those of the parent society, except that they are founded on a democratic basis, there being no council, and the general management of the branch and its business being vested in the members. But the branch may delegate any of its powers to committees composed of not less than five members. The annual subscription is $5 \mathrm{~s}$.

The branch has held four meetings during the present session, two of which have been devoted to the consideration of the Public Health (London) Act, 189r, and of the bye-laws to be made by sanitary authorities under this Act. The decisions of the branch as to the meaning of certain sections of the Act are of importance, and are set out below :-

Section I casts the obligation upon every metropolitan sanitary authority of making from time to time a house-to-house inspection of its district.

Section 3.-No agreement was arrived at as to a written intimation to owner or occupier being necessary in every case of nuisance, prior to the service of a statutory notice.

Section 4.-No agreement was arrived at as to the desirability of a specification of the works necessary to abate or prevent the recurrence of a nuisance being included in the statutory notice served upon owners or occupiers.

Section 5.-It was considered to be desirable that arrangements should be made by the authorities for sufficient time to be given by the petty sessional courts to hear cases arising out of complaints of nuisances and other matters connected with public health administration.

Section 55, Sub-section iv.-It was considered that it would be the proper course to furnish the head teacher of a school attended by a patient notified to be suffering from infectious disease, or attended by any child an inmate of the infected house, with a copy of the medical practitioner's certificate, in accordance with the words of the section.

Bye-laze's under the Public Health (London) Act, I891.-The opinion was freely expressed that the draft model bye-laws submitted by the Local Government Board for the flushing of water-closets, and for securing the cleanliness of cisterns, were of a very colourless and vapid character, and were far from being as definite, precise, and serviceable as the regulations made under the Metropolis Water Act, $x 891$, which have been in force in the metropolis, as part of the water companies' regulations, for the past twenty years. It is in fact difficult to see what can be the use of a bye-law like the following: "The occupier of any premises, in or for which any water-closet shall be provided, shall cause such water-closet to be at all times properly supplied with a sufficient quantity of water for securing its effective action." "Properly supplied," "sufficient quantity," and "effective action," are terms upon which owners and health officers are not likely to put the same interpretation; and it is surely the chief object and aim of a bye-law to put into definite language, incapable of misconstruction, the principles and intentions of the Act of Parliament under which bye-laws are to be made. Acts of Parliament cannot descend to petty details, but bye-laws can; surely, therefore, a bye-law for flushing closets should specify that the cistern used to flush the closet should be separate from that used for storing drinking water, and that it should be so constructed as to discharge not less than two gallons of water at each flush through a supply pipe of not less than $1 \frac{1}{4}$ inch internal diameter.

It is the duty of the London County Council to make bye-laws for waterclosets, the local sanitary authorities being only permitted to make bye-laws for their flushing, so that it is to be hoped that the London County Council will specify, as exactly as the branch has done in its amendments to the L.G.B. model, what precise kinds of waterclosets will be permitted. Long hoppers with side inlets, pan closets with spreaders must certainly be utterly discarded, or the most effectual bye-laws made by vestries for flushing cisterns and supply pipes will be worthless. The above is an illustration of the kind of muddle that is likely to arise from the extraordinary division of powers between local and central authorities, unless very great care is taken.

The amendments of the branch to the model bye-law for flushing closets, specifies those particulars which are so unaccountably missing in the model. In the same way, the branch's amendment to the model bye-law for securing the cleanliness of tanks and cisterns used for storing drinking water, insists upon the disconnection of all overflow and waste pipes of cisterns from waterclosets or drains, a most important matter, which is utterly ignored in the model. The branch's amendment also insists upon the cistern being so placed and constructed as to be conveniently cleansed-a very important practical detail. The branch also inserts. an important amendment in the model bye-law for the prevention of nuisances arising from offal, carrion, filth, fish, etc. It insists upon such foul matters being removed in closely-covered metallic receptacles, or in suitable covered carts, so as to 
prevent any escape of any contents, or of any stench, such removal to be carried out every 24 hours in the night time.

It will be seen from the above that the branch's time at its meetings is devoted to metropolitan public health business. The new Public Health Act renders it very desirable that metropolitan health officers should meet to discuss their new duties and responsibilities, and to concert measures or metbods of working which will be acceptable to all the London districts, and so secure the much desired uniformity of action. The meetings have been well attended, and so far the branch has done useful public work. The above account may possibly arouse an increase of interest amongst those who ought to be its members.

Louis C. Parkes, Hon. Sec.

\section{WORKING OF THE SCOTCH PUBLIC HEALTH ACTS.}

\section{Deputations to THE LORD ADvocate.}

ON December 21 st, 1891 , the Lord Advocate (Sir Charles Pearson) received in Edinburgh a deputation of medical officers of Health in Scotland, who submitted memorials calling for amendments in the Public Health Acts. The deputation was from the Society of Medical Officers of Health for Scotland, and included: Dr. Littlejohn, Edinburgh; Dr. Russell, Glasgow ; Dr. Simpson, Perth; Dr. M'Clintock, Lanarkshire; Dr. Ross, Dumfries; Dr. Macdonald, Ayrshire; Dr. Brock, Mid-Lothian; Dr. Alexander, Caithness; Dr. M'Vail, Stirling and Dumbarton; Dr. Graham, Perthshire; and Dr. Campbell Munro, Renfrewshire, secretary of the society.

Dr. LitTLEJOHN briefly introduced the deputation.

Dr. M'VAIL submitted a memorial from the society to the Marquis of Lothian, Secretary for Scotland, bringing under bis Lordship's notice the condition of the law with regard to certain nuisances as they occurred in villages. The memorialists called attention to the difficulties attend. ing the disposal of accumulations of excrement and house refuse, and suggested that the Public Health Acts should be amended, so as to sanction the formation of special cleansing districts, on the same lines as were already laid down in the case of special drainage districts and special water supply districts. In regard to rating for cleansing purposes within such special districts, it would fall to be considered whether the present limit of $2 \mathrm{~s} .6 \mathrm{~d}$. in the pound would in all cases be sufficient to cover the additional expenditure. Of course payment by rate would merely be a substitute for payment by voluntary arrangement, so that there would be no real addition to the ratepayers' outlay, excepting such as might in any case result from the better carrying out of the removal of nuisarces. Indeed, a general scavenging contract carried out by Local Authority would probably be much more economical than the numerous individual contracts that would, under the existing law, have to be entered into for attaining the same object. If the Public Health Acts were amended according to the prayer of the memorial, and if, thereafter, it appeared that in any existing special water supply district the public health rate approached so nearly to the limit allowed by law as to bar the way to the forma. tion of a coterminous special cleansing district, the difficulty could be got rid of by adopting the Public Health (Scotland) Act Amendment Act of 189r. But, in any case, it appeared to the memorialists that charges for cleansing purposes could much more appropriately be classed as public health rates than could charges for the providing of any. thing in the nature of a prime necessary of life, such as potable water.

Dr. Litruejorn, in introducing Dr. Russell, said the deputation had further to bring under his Lordship's notice a difficulty under which they laboured owing to the Board of Supervision requiring them to give certain vital statistics at the end of each year, which they found it impossible to give in a satisfactory manner.

Dr. RUSSELL then submitted a memorial from the society to his Lordship. The memorialists pointed to the stagnation in general sanitary legislation affecting Scotland, and referred to certain items of legislation existing in England which they believed might be extended to Scotland without opposition. The first of these concerned the acquisition of a knowledge of the vital statistics of their districts by medical officers of health. This meant not mere general figures representing aggregates of births and deaths, but details of the locality of each birth, and the name, address, age, occupation, disease, etc., of each person who died. At this time of day it was unnecessary to say a word in regard to the importance of this knowledge. It lay at the very root of preventive action, which to be successful must be precise. The memorialists suggested two ways in which the necessary co.operation of the registrars and the local authorities might be secured in Scotland-( 1 ) by extending the 28 th section of the Act 37 and 38 Victoria, chap. 88, applying it to births as well as deaths to Scotland in the Single Clause Act, and (2) by the exercise of the powers conferred upon the Secretary for Scotland to make regulations "for the discharge of the duties of the Registrar-General and of the registrars and assistant registrars, so that such regulations be not contrary to the provisions of this Act." The memorialists further directed attention to two Acts of Parliament designated respectively the "Infectious Diseases Prevention Act, 1890," and "The Public Health Acts Amendment Act, 1890 ." The memorialists could not hazard a guess why Scotland should have been excluded from the great advantages of those Acts, more especially while the " Infectious Diseases (Notification) Act" was made applicable. This latter fact made the policy of the exclusion perfectly incoherent, because the full advantages of compulsory notification could not be reaped without the other Acts.

Dr. LitTLEjohn said the deputation did not expect a decided expression of opinion from his Lordship, because they knew he must look into the Acts narrowly.

The Lord-Advocate said that Lord Lothian had sent him word that he greatly regretted being unable to be present; but he (the Lord.Advocate) had been fully furnished for this matter, and should be able to lay before Lord Lothian what had been submitted to him. This first matter was an interesting point, and he was afraid it was only too certain that there were facts existing in various parts of the country which supported some such demand as the deputation made, although he did not know how far it might not be a good answer-and that was one of the things he should have to considerthat the existing powers might now be utilized in a way in which they had not hitherto been. It was not a pleasant thing to have prosecution upon prosecution, but at the same time those powers undoubtedly existed as soon as those ashpits spoken of amounted to a nuisance. It seemed to him pretty certain that under the existing law these things could be put down. It was rather, he 